\title{
Tourism Sector Village Development Sebuah Kajian Pustaka Terstruktur (Systematic Literature Review)
}

\author{
Muhammad Naufal Ammar \\ Program Studi Ilmu Pemerintahan, Universitas Muhammadiyah Malang. \\ Email: ammarrr986@gmail.com
}

\begin{abstract}
Abstrak; Penelitian memiliki tujuan untuk dapat menggali pemahaman tentang perencanaan pembangunan di wilayah perdesaan secara berkelanjutan dengan menggunakan metode Literature Review yaitu dengan membaca dan menggali kembali pokok-pokok pikiran mengenai tema yang sama untuk dapat menambahkan ide baru serta pendapat penulis mengenai topik yang akan diangkat. Kemudian dengan digunakannya review paper pada penelitian ini yang berbasis literature review penulis juga dapat melihat sisi kekurangan dari penelitian-penelitian sebelumnya sehingga dengan hal ini penulis dapat melakukan perbaikan dan perumusan yang lebih teratur. Beberapa hal yang sangat perlu dilakukan sebelum melakukan review artikel suatu jurnal, diantaranya yaitu: Mencari jurnal yang memang sesuai dengan topik yang akan diangkat oleh peneliti, Membaca dengan teliti dan memahami keseluruhan isi dari jurnal, dan peneliti perlu mencoba untuk menuliskan kembali dengan pemahaman dan ide penulisan sendiri sehingga dapat mudah dipahami oleh peneliti dan yang membaca hasil dari tulisan. Berdasarkan hal itu penelitian ini mereview jurnal adalah tulisan yang berisi tentang ringkasan-ringkasan penelitian ilmiah terhadap topik-topik tertentu. Penelitian ini juga mengungkap bahwa di dalam sebuah proses perencanaan pembangunan pedesaan sangat perlu memiliki sebuah padoman terhadap dampak-dampak sebab akibat dari perencaaan pembagunan sehingga tidak menyebabkan terjadi permasalahan dalam proses pembangunanya dengan melihat pada dampak lingkungan yang nantinya akan diakibatkan dari pembangunan proyek apalagi di tingkatan desa. Dimana desa masih banyak yang memiliki karakteristik tradisional pada masyarakatnya dan di desa masih kental akan budayanya. Proses perencanaan pembangunan harus dapat memikirkan kebutuhan dan keuntungan masyarakat desa tanpa merusak ekosistem di desa dan memberikan efek yang baik kepada masyarakat terutama pada bidang perekonomi dan kesejahterannya.
\end{abstract}

\section{Kata Kunci: Perencanaan Pembangunan, Pedesaan, Pariwisata}

\begin{abstract}
The aim of this research is to be able to explore an understanding of development planning in rural areas in a sustainable manner using the Literature Review method, namely by reading and reexploring the main points of the same theme to be able to add new ideas and writers' opinions on the topics to be raised. Then by using a review paper in this study based on literature review, the author can also see the shortcomings of previous studies so that with this the author can make improvements and a more orderly formulation. Some things that really need to be done before reviewing a journal article, including Looking for journals that are in accordance with the topic to be raised by the researcher, reading carefully and understanding the entire contents of the journal, and researchers need to try to rewrite with understanding and ideas writing itself so that it can be easily understood by researchers and those who read the results of the writing. Based on this, this study reviews journals which are writings that contain summaries of scientific research on certain topics. This research also reveals that in a rural development planning process it is very necessary to have a guideline of the causal impacts of development planning so that it does not cause problems in the development process by looking at the environmental impacts that will later be caused by project development, especially at the village level. . Where there are still many villages that have traditional characteristics in their communities and in the village are still strong in their culture. The development planning process must be able to think about the needs and benefits of rural communities without destroying the ecosystem in the village and giving good effects to the community, especially in the field of economy and welfare.
\end{abstract}

Keywords: Development Planning, Rural, Tourism 


\section{Pendahuluan}

Dalam sebuah penelitian untuk mendapatakn data yang ingin diketahui mengenai suatu hal diperlukan adanya analisis terhadap variabel-variabel yang menjadi pisau analisis berupa data atau penemuan baru dari suatu hal yang hendak diteliti, dalam hal ini untuk mengali sebuah sumber data yang skiranya tidak dapat dilakukan secara langsung maka dapat menggunakan metode mereview papper. Melalui proses review papper dapat menambah pemahaman kita dalam menganalisis data serta membangun argumentasi untuk menyatakan pendapat mengenai judul yang kita angkat, dengan adanya review papper juga dapat melihat pandangan atau prespektif dari penulis lain mengenai masalah yang diangkat sehingga dapat memberikan acuan kepada penulis lain untuk mengembangkan pendapatnya. Selain itu dengan menggunakan review papper penulis juga dapat melihat kekurangan dari peeliti-penelitian sebelumnya sehingga dapat melakukan perbaikan dan perumusan yang lebih teratur. Setidanya terdapat beberapa hal yang perlu kita lakukan sebelum mereview artikel suatu jurnal, diantaranya yaitu: Menemukan jurnal yang sesuai dengan topik penelitian yang diangkat (bedakan jurnal dengan artikel atau tutorial, Membaca keseluruhan dari isi jurnal, dan Mencoba untuk menuliskan kembali dengan bahasa sendiri pengertian dari jurnal/paper tersebut. Sehingga dari penjelasan tersebut dapat ditarik kesimpulan bahwa review jurnal merupakan teks yang berisi tentang ringkasan penelitian ilmiah terhadap topik-topik tertentu. Hal ini tentusaja bisa dianggap sebagai ringkasan atau evaluasi dari tulisan orang lain. Adapun review jurnal ditulis dengan tujuan untuk memberikan pemahaman yang lebih baik tentang topik tertentu, sehingga dapat membantu individu memahami beberapa topik tanpa membaca seluruh buku atau berbagai jenis dokumen publik. Dengan ini maka dapat melihat analisis peneliti mengenai Perencanaan Pembangunan Area Pedesaan Berkelanjutan.

Pariwisata adalah salah satu jenis industri karya yang mampu menciptakan pertumbuhan ekonomi karena dapat menyediakan lapangan kerja, peningkatan penghasilan, standar hidup dan menstimulasi sektor-sektor produksi lainnya sehingga berdampak pada pembangunan ekonomi. Pembangunan ekonomi itu sendiri merupakan proses kenaikan pendapatan total dan pendapatan perkapita dengan memperhitungkan pertambahan penduduk dan disertai dengan perubahan fundamental dalam struktur ekonomi suatu wilayah. Pembangunan ekonomi tak dapat lepas dari pertumbuhan ekonomi (economic growth) dimana pembangunan ekonomi mendorong pertumbuhan ekonomi, dan pertumbuhan ekonomi memperlancar proses pembangunan ekonomi. Dari sudut ekonomi, sedikitnya terdapat delapan keuntungan pengembangan pariwisata pariwisata yaitu peningkatan kesempatan usaha, kesempatan kerja, peningkatan penerimaan pajak, penerimaan pendapatan, percepatan pemerataan pendapatan, peningkatan nilai tambah produk kebudayaan, memperluas pasar produk, meningkatkan dampak multiplier effect dalam perekonomian akibat pengeluaran wisatawan, investor maupun perdagangan keluar negeri (Yoeti, 2017) 
Selain itu dalam konteks transisi dari "Cina Pedesaan-Asli" ke "Cina PedesaanPerkotaan", desa-desa pinggiran kota telah mengalami rekonstruksi format, industri, dan fungsi yang cepat. Bertujuan untuk mengungkap karakteristik evolusi dan kekuatan pendorong, studi ini memilih She Village, yang terletak di daerah pinggiran kota Nanjing, untuk menganalisis perubahan morfologi dominan dan resesif penggunaan lahan dengan menggunakan penilaian pedesaan partisipatif, penginderaan jauh, dan sistem informasi geografis. Hasil penelitian menunjukkan bahwa She Village mengalami tiga tahap, termasuk pengembangan industri, restorasi ekologi, dan pengembangan industri jasa, dari 1980 hingga 2018, dengan mode pengelolaan yang lebih beragam, penggunaan lahan multifungsi, dan fragmentasi lahan yang semakin intensif. Penggeraknya termasuk sumber daya alam, pertumbuhan populasi, kebijakan Grain for Green, permintaan pasar perkotaan, dll., Yang intensitasnya menunjukkan tren "naik-naik-naik", "naik-turunturun", "sesekali", dan "naik-turunkan-naikkan" secara bergantian. Desa wisata menjalani tiga tahap pembangunan industri, pembangunan pertanian, dan pengembangan industri jasa, dengan karakteristik berkala didorong oleh kebijakan topdown, kekuatan desa endogen, dan radiasi dan difusi kota. Penelitian ini memperdalam pemahaman tentang proses pembangunan desa suburban dan menjadi acuan dalam pembuatan dan perencanaan kebijakan pertanahan di desa lain yang sejenis.

\section{Literatur Review}

Studi ini mengidentifikasi dua proses alternatif tetapi berpotensi simultan untuk pembangunan pedesaan di Cina. Salah satunya adalah pendekatan 'bottom-up' di mana individu dan kelompok penduduk desa bekerja secara inovatif dalam mengembangkan peluang konstruksi bangunan baru, yang didorong oleh metode desain dan konstruksi kontemporer dan asli. Alternatif pendekatan 'top-down' dikaitkan dengan perubahan yang disebabkan oleh pengaruh eksternal, seperti arahan yang diberikan dari sumber pendanaan, dan dorongan untuk penggunaan pengetahuan dan teknologi tertentu; ini kemudian disaring melalui sistem administrasi desa. Dua desa etnis dipelajari di provinsi Yunnan, sebuah wilayah dengan populasi pedesaan berpenghasilan rendah yang lebih besar daripada wilayah lain. Setiap desa memamerkan budaya tradisional yang kuat dan masing-masing telah mengalami pembangunan kembali wisata yang berbeda selama lebih dari sepuluh tahun. Studi kasus menunjukkan adanya ketidaksesuaian antara kategorisasi akademik hunian di desa berdasarkan representasi budaya tradisional yang diciptakan oleh bahan dan teknik, dan persepsi warga desa itu sendiri tentang makna sosial dan budaya dari rumah dan ruang mereka di desa. Hasilnya menunjukkan bahwa arsitek dan desainer dapat memiliki keterlibatan yang berbeda dalam pembangunan pedesaan melalui pembangunan platform untuk diskusi dan pengambilan keputusan, digunakan dengan dan di antara pemangku kepentingan, dan yang dapat menghubungkan dua arah pendekatan yang berbeda.

Dengan urbanisasi yang cepat di Cina, pola permukiman berubah secara dramatis. Meskipun ada banyak penelitian tentang perubahan di kota-kota Cina, kita tahu relatif 
sedikit tentang pedesaan meskipun transformasi besar sedang terjadi di pedesaan Cina. Pada pergantian abad ke-21, pemukiman tradisional Tionghoa pedesaan, desa alami dihancurkan secara sistematis, dan penduduk desa dipindahkan ke apartemen dan komunitas perkotaan dengan skala dan kecepatan yang mencengangkan. Urbanisasi paksa yang belum pernah terjadi sebelumnya dengan transformasi sosial ekonomi dan spasial yang mendalam sedang terjadi di sebagian besar pedesaan Cina. Bab ini bertujuan untuk memahami dinamika dan dampak dari urbanisasi yang pesat di pedesaan Cina dengan mengambil pedesaan Provinsi Jiangsu sebagai studi kasus. Penulis berpendapat bahwa keinginan pemerintah daerah akan lebih banyak lahan konstruksi untuk pembangunan ekonomi di bawah sistem manajemen penggunaan lahan yang ketat dan sistem pendapatan berbasis lahan adalah akar penyebab urbanisasi paksa di pedesaan Cina, yang selanjutnya didorong oleh seruan pemerintah pusat untuk mengembangkan pedesaan baru sosialis. Meskipun penduduk desa dapat memperoleh manfaat dari kondisi perumahan yang lebih baik, mereka menderita konsekuensi sosial dan ekonomi yang serius. Urbanisasi yang dipaksakan ini sangat merugikan orang tua dan orang miskin, yang membayangi kampanye untuk pedesaan modern dan masyarakat yang harmonis

Pembangunan perumahan dan industri informal di apa yang disebut desa-desa perkotaan telah menjadi ciri utama dari urbanisasi Tiongkok baru-baru ini. Pada artikel ini kita akan membahas perkembangan desa perkotaan di salah satu kota paling dinamis di Cina - Shenzhen. Artikel pertama mengulas proses urbanisasi dan migrasi di wilayah dan munculnya desa-desa perkotaan. Kemudian memeriksa perkembangan perumahan informal, komersial dan industri di desa-desa ini. Kami menganalisis politik urbanisasi desa dan menyoroti hubungan penting antara migrasi dan pembangunan desa informal. Kami menekankan kontribusi yang dibuat oleh desa-desa perkotaan dalam menyediakan perumahan dan pekerjaan yang terjangkau bagi penduduk berpenghasilan rendah selama urbanisasi yang cepat dan mendesak pertimbangan yang hati-hati terkait dengan pembangunan kembali desa-desa tersebut secara tergesa-gesa dan berskala besar. Kami menyimpulkan bahwa pembangunan kelurahan merupakan bagian yang sangat penting dari proses urbanisasi

Desa Xu Fu, Ningbo LID, Perencanaan Konstruksi Pedesaan Intensif adalah proyek kerjasama antara Universitas Zhejiang dan Institut Teknologi Ningbo yang dinamai "Program dukungan Sains dan Teknologi Nasional Lima Tahun ke-12 - demonstrasi komprehensif dari teknologi kunci pembangunan pedesaan yang indah dalam daerah urbanisasi di Delta Sungai Yangtze ". Rencana ini berfokus pada pembangunan pedesaan yang intensif sebagai bagian dari pembangunan pedesaan dan proyek konstruksi yang menerapkan prinsip pembangunan berdampak rendah. Desa Xu Fu terletak di Wilayah Delta Sungai Yangtze. Saat ini, pertumbuhan pedesaan membawa dampak pembangunan yang tinggi, sebagai akibat dari pertumbuhan urbanisasi yang pesat sehingga menimbulkan beberapa masalah, seperti efisiensi penggunaan lahan yang rendah, pemukiman pedesaan yang terpencar-pencar, permukiman penduduk yang lebih banyak, 
jalan-jalan pedesaan yang menutupi, dll. Sementara itu, desa $\mathrm{Xu} \mathrm{Fu}$ ingin mengembangkan potensi pariwisatanya. Oleh karena itu, pembangunan pedesaan yang intensif harus dilakukan untuk menghindari efek yang parah. Hasil proyek diharapkan dapat meningkatkan kualitas dan taraf perencanaan, desain, dan konstruksi permukiman pedesaan; memperbaiki lingkungan hidup mereka; menghemat lahan konstruksi dan penggunaan air; dan meningkatkan efisiensi energi. Tujuan dari penelitian ini adalah untuk mengkaji Konstruksi Pedesaan Intensif Pembangunan Berdampak Rendah (LID) di Desa $\mathrm{Xu} \mathrm{Fu}$, Kota Ningbo melalui perspektif ketahanan pedesaan. Makalah ini akan mendeskripsikan rencana proyek terlebih dahulu, kemudian mengulasnya melalui perspektif ketahanan pedesaan. Makalah ini akan menguraikan teori ketahanan pedesaan dan kemudian meninjau ketahanan pedesaan melalui dua bagian; Bagian pertama adalah mengidentifikasi ketahanan desa dalam pembangunan infrastruktur pedesaan berdasarkan kriteria yang dibuat oleh Ayyob S. dan Yoshiki Y. (2014), tentang kriteria ketahanan kota, dan bagian kedua adalah meninjau ketahanan Desa Xu Fu melalui Arup Resilience Qualities (2012). Mempertimbangkan tiga domain ketahanan pedesaan (ekonomi, ekologi, dan budaya

Dalam konteks transisi dari "Cina Pedesaan-Asli" ke "Cina Pedesaan-Perkotaan", desa-desa pinggiran kota telah mengalami rekonstruksi format, industri, dan fungsi yang cepat. Bertujuan untuk mengungkap karakteristik evolusi dan kekuatan pendorong, studi ini memilih She Village, yang terletak di daerah pinggiran kota Nanjing, untuk menganalisis perubahan morfologi dominan dan resesif penggunaan lahan dengan menggunakan penilaian pedesaan partisipatif, penginderaan jauh, dan sistem informasi geografis. Hasil penelitian menunjukkan bahwa She Village mengalami tiga tahap, termasuk pengembangan industri, restorasi ekologi, dan pengembangan industri jasa, dari 1980 hingga 2018, dengan mode pengelolaan yang lebih beragam, penggunaan lahan multifungsi, dan fragmentasi lahan yang semakin intensif. Penggeraknya termasuk sumber daya alam, pertumbuhan populasi, kebijakan Grain for Green, permintaan pasar perkotaan, dll., Yang intensitasnya menunjukkan tren "naik-naik-naik", "naik-turunturun", "sesekali", dan "naik-turunkan-naikkan" secara bergantian. Desa wisata menjalani tiga tahap pembangunan industri, pembangunan pertanian, dan pengembangan industri jasa, dengan karakteristik berkala didorong oleh kebijakan topdown, kekuatan desa endogen, dan radiasi dan difusi kota. Penelitian ini memperdalam pemahaman tentang proses pembangunan desa suburban dan menjadi acuan dalam pembuatan dan perencanaan kebijakan pertanahan di desa lain yang sejenis.

BAZNAS sebagai pusat pengelolaan zakat nasional menyelengggarakan program pemberdayaan zakat dalam bentuk program pengembangan desa binaan yaitu program Zakat Devoplement Community.Program ini adalah pemberian bantuan zakat produktif pada desa-desa yang membutuhkan. Dalam membangun dan memberdayakan desa diperlukan suatu standar pengukuran sebagai acuan bagi stakeholder seperti pemerintah guna perencanaan pengembangan desa dengan tepat.Penelitian ini menggunakan metodemixed method research, yaitu 
gabunganmetode kualitatif dan kuantitatif. Alat analisis yang digunakan adalah Indeks Desa Zakat (IDZ) dengan penghitungan metode multi-stage weighted index.Penelitian ini bertujuan untuk menganalisis desa Sungai Dua dan mengukurnya apakah diprioritaskan untukdibantu dana zakat atau tidak.Hasil penelitian menunjukkan bahwa desa Sungai Dua dikategorikan Baik dengannilai sebesar 0.65 dan diinterpretasikan tidak diprioritaskan untuk dibantu dana zakat.

Ekowisata telah dipromosikan di banyak wilayah di Indonesia sebagai platform yang layak untuk mengurangi emisi dari deforestasi dan degradasi hutan di negara berkembang (REDD +) dengan memberikan insentif kepada masyarakat lokal untuk upaya konservasi hutan mereka. Kajian ini bertujuan untuk menemukan peluang penerapan REDD + di Bali melalui analisis segmentasi pasar ekowisata, dan untuk memberikan implikasi kebijakan bagi negara berkembang lain dalam keadaan serupa. Hasilnya menunjukkan bahwa dua cluster - "turis bertanggung jawab yang mencari alam" dan "turis bertanggung jawab yang mencari kesehatan" - dipilih sebagai cluster target Bali. Karena keduanya memiliki motivasi yang lebih tinggi dan sikap yang lebih bertanggung jawab dibandingkan cluster lainnya, mereka tidak hanya mampu menjaga hubungan simbiosis antara destinasi ekowisata dan pengunjung, tetapi juga menarik wisatawan potensial dengan karakteristik serupa, yang pada akhirnya berkontribusi pada bisnis pariwisata berkelanjutan di Indonesia. wilayah. Kesimpulannya, membangun strategi pemasaran berdasarkan pemahaman para wisatawan akan mendorong pelestarian hutan secara efektif, sekaligus memainkan peran penting dalam implementasi REDD + dengan membawa pendapatan pariwisata berkelanjutan bagi masyarakat lokal.

Makalah ini menyajikan pemahaman tentang kontribusi yang dibuat oleh pariwisata terhadap pengentasan kemiskinan di daerah pedesaan tertentu di Selangor, Malaysia. Program homestay pedesaan sebagai produk pariwisata yang layak di Malaysia memiliki skala yang relatif kecil dan masih merupakan pasar yang pertumbuhannya lambat meskipun berbagai insentif ditawarkan kepada operator oleh pemerintah untuk mengembangkan pasar ini. Kemiskinan merupakan akar penyebab berbagai penyakit sosial seperti buta huruf, kriminalitas, penyalahgunaan narkoba dan tingginya angka perceraian. Meskipun pariwisata telah diadopsi sebagai strategi pengentasan kemiskinan di Selangor, hal itu belum sepenuhnya dimanfaatkan oleh masyarakat pedesaan dan mereka yang telah mengalami kesulitan untuk mempertahankannya. Penelitian ini dilakukan dengan tujuan menyusun model (atau mengidentifikasi variabel) yang akan menjamin keberlanjutan ekonomi program homestay pedesaan di Selangor, Malaysia. Melalui analisis faktor, variabel keterlibatan masyarakat dalam kegiatan pariwisata diidentifikasi.

\section{Metode Penelitian}

Penelitian ini memiliki tujuan untuk mengkaji sebuah artikel yang memiliki keterkaitan dengan perencanaan pembangunan pedesaan pada bidang pariwisata. Sumber data yang didapat ialah berupa kumpulan artikel-artikel yang dipublikasikan 
pada jurnal ilmiah yang bereputasi internasional. Adapun kajian ini didasarkan pada beberapa pertanyaan antara lain, yaitu:

1. Apa tema yang dominan dalam pembahasan tentang perencanaan pembangunan pedesaan pada bidang pariwisata?

2. Bagaimana hubungan antara perencanaan pembangunan dan bidang pariwisata?

3. Apa saja topik yang berhubungan dengan penelitian tentang perencanaan pembangunan pedesaan pada bidang pariwisata?

4. Bagaimana jenis pemetaan yang digunakan dalam membahas tentang perencanaan pembangunan pedesaan pada bidang pariwisata?

5. Konsep apa yang digunakan dalam studi tentang perencanaan pembangunan pedesaan pada bidang pariwisata.

Beberapa pertanyaan-pertanyaan tersebut akan dijadikan sebagai acuan kajian yang didasarkan pada penemuan artikel pada database SCOPUS. Artikel yang nanti direview didasarkan pada dua tahapan yaitu diantaranya: Pencarian artikel dan Pemetaan topik.

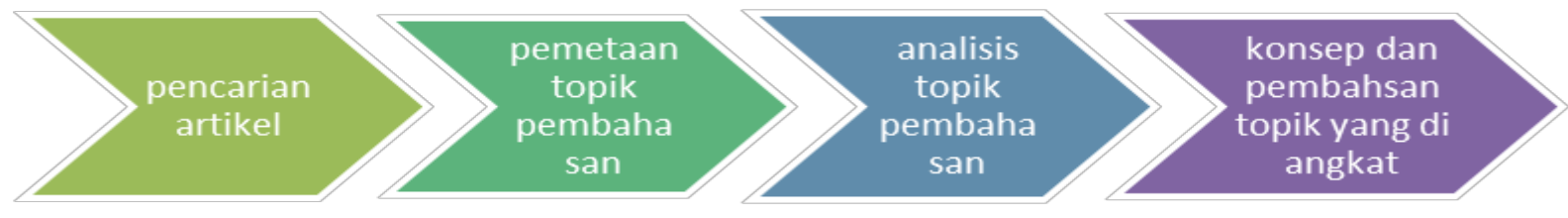

Gambar 1. proses review artikel

Adapun artikel yang berkaitan dengan topik pembahasan diperoleh melalui cara berikut. Pertama, mengidentifikasi artikel. Hal ini dilakukan dengan mencari data di database scopus dengan memasukan kata kunci "Perencanaan pembangunaan perdesaan Pada Bidang Pariwisata" pada kolom pencarian dengan pembatasan tahun 2020 hingga tahun 2021. Pencarian tersebut mendapatkan jurnal sebanyak 3.967 artikel yang relevan dengan topik yang diangkat. Tahapan kedua ada memverifikasi artikel yang seda dikumpulkan. Pada verifikasi ini menghasilkan 260 artikel yang dianggap sesuai dengan topik penelitian, kemudian, dari angka tersebut diverifikasi kembali dan menyisakan 76 artikel yang benar-benar memiliki relevansi dengan apa yang akan dibahas dalam kajian ini.

\section{Hasil Penelitian dan Pembahasan}

a. Keterkaitan Dan Pengelompokan Tema Dalam Perencanaan Pembangunan Desa Bidang Pariwisata 
Vosviewer adalah suatu aplikasi yang digunakan untuk memvisualkan bibliografi atau data yang berisikan field bibliografi ( judul, pengarang, penulis, jurnal dll ). Didalam dunia penelitian Vosviewer digunakan untuk analisis bibliometric, mencari topik yang masih ada peluang untuk diteliti, mencari referensi yang paling banyak digunakan pada bidang tertentu dan lainnya. Data bibliografi dapat diambil dari Web of Science, Scopus, Dimension, dan Pubmed. Selain itu dapat melalui format dataset RIS, Endnote, dan RefWork. Hasil yang didapat bervariasi sesuai dengan berapa banyak data yang digunakan. Akan ada variasi besar kecilnya lingkaran serta garis yang menghubungkan. Hal ini berkaitan dengan topik yang paling dominan atau tidaknya pada data yang digunakan. Terdapat 3 tampilan visualisasi di Vosviewer ini yaitu Network, Overlay, dan Density Visualization. Berikut penjelasan 3 visualisasinya :

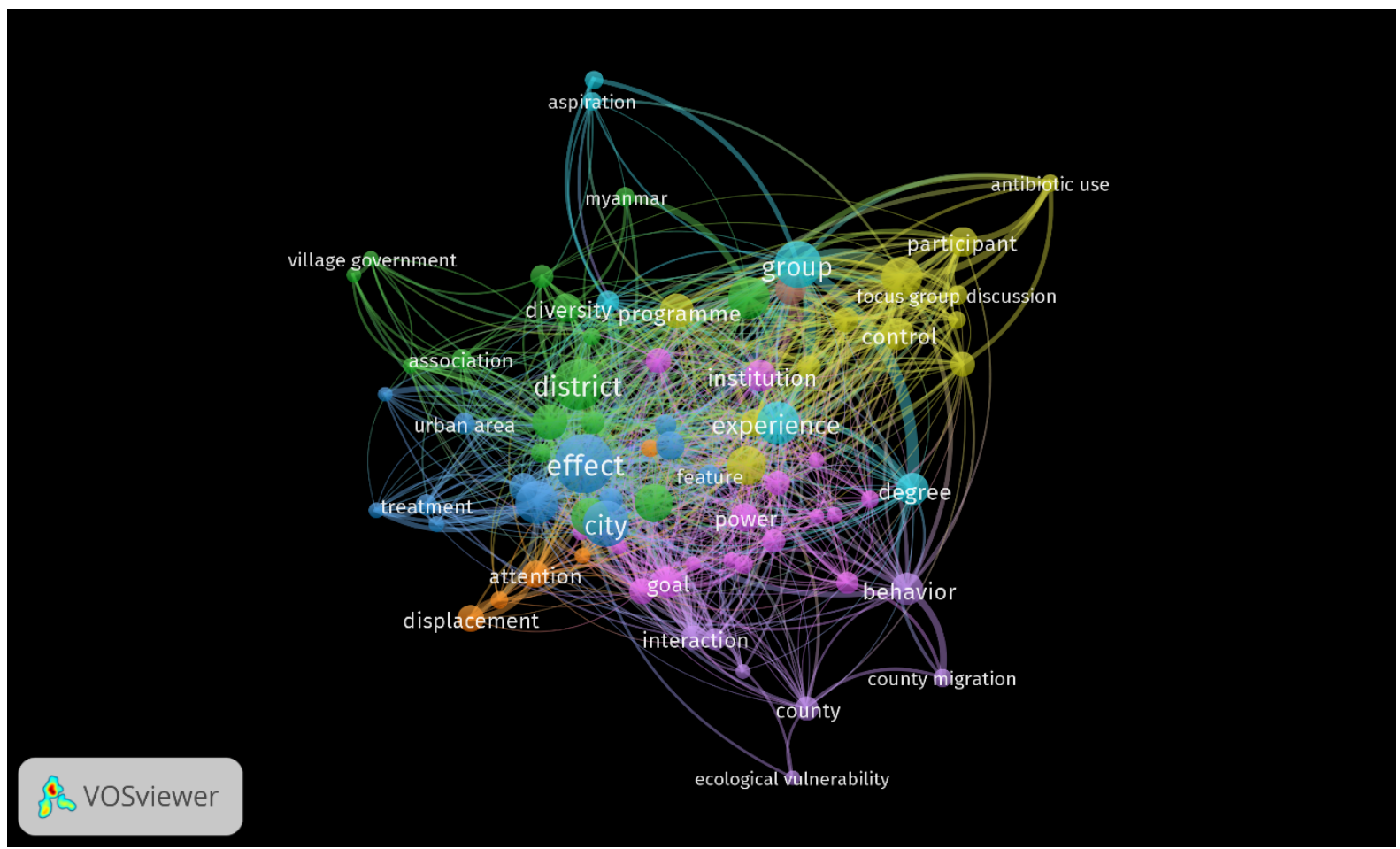

Gambar 2. Menampilkan warna yang berbeda di setiap kluster yang ada.

\section{1) Network Visualization}

Network Visualization berfungsi untuk memperlihatkan jejaring antar topik yang divisualkan. Berdasarkan 260 jurnal yang dicari melalui Scopus yang bertemakan Village Development dengan menggunakan aplikasi vosviewer telah mendapatkan hasil yaitu 76 item 8 cluster. Item tersebut digambarkan dengan beberapa warna seperti pada gambar diatas. Bentuk lingkaran dan tulisan yang berukuran lebih besar menggambarkan bahwa mereka adalah topik yang paling dominan dalam cluster masing-masing. Sedangkan bentuk lingkaran dan tulisan lebih kecil, mereka adalah topik pendamping atau tambahan yang digambarkan dengan cabang-cabang atau garis sesuai dengan warna cluster masing-masing. Berikut pembagian menurut beberapa menurut Network Visualization: 
Pada cluster 1 terdapat 2 topik yang paling dominan adalah "Ecperience" dan "Power" yang ditandai dengan warna Biru. Didalam cluster ini terdapat beberapa cabang atau topik tambahan yaitu, capital, contribution, financialization, social capital, village level. Pada Cluster 2 terdapat 1 topik yang paling dominan adalah "Village Government" yang ditandai dengan warna hijau. Didalam cluster ini terdapat beberapa cabang atau topik tambahan yaitu, community participation, district, divercity, implication, originality value. Pada cluster 3 terdapat 2 topik yang paling dominan yaitu "Benefit" dan "Devolopment" yang ditandai dengan warna Kuning. Didalam cluster ini terdapat beberapa cabang atau topik tambahan yaitu city, efficiency, possibility, distribution, value, urban area. Pada cluster 4 terdapat 1 topik yang paling dominan yaitu "district" yang ditandai dengan warna Hijau. Didalam cluster ini terdapat beberapa cabang atau topik tambahan yaitu attitude, benefit, control, intervention, response. Pada cluster 5 terdapat 1 topik yang dominan yaitu "Behavior" yang ditandai dengan warna Ungu. Didalam cluster ini terdapat beberapa cabang atau topik tambahan yaitu interaction, evolution, rural society. Pada cluster 6 terdapat 1 topik yang dominan yaitu "Aspiration" yang ditandai dengan warna Ungu. Didalam cluster ini terdapat beberapa cabang atau topik tambahan yaitu degree, experience, group, investment. Pada cluster 7 terdapat 1 topik yang dominan yaitu "Urban Development" yang ditandai dengan warna Ungu. Didalam cluster ini terdapat beberapa cabang atau topik tambahan yaitu attention, urban village, validity. Pada cluster 8 terdapat 1 topik yang dominan yaitu "society" yang ditandai dengan warna Ungu.

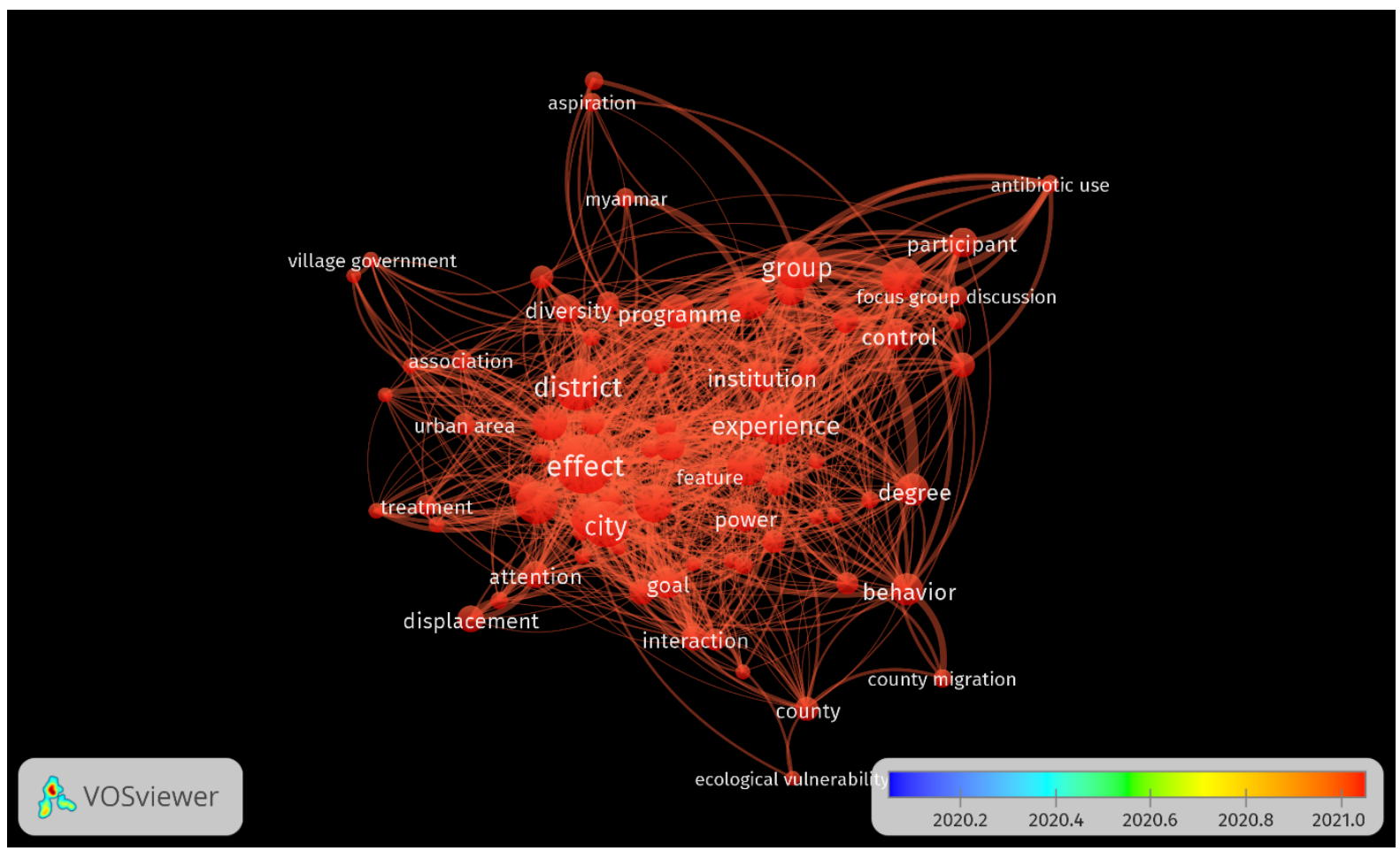

Gambar 3. Konsep Dominan Dilihat dari Overlay Visualization 


\section{2) Overlay Visualization}

Berdasarkan 260 jurnal yang telah dicari melalui scopus dengan tema Development Planning in Developing Human Resources terdapat 76 item 8 cluster. Item tersebut digambarkan dengan beberapa warna seperti pada gambar diatas. Berikut penjelasan menurut beberapa cluster: Pada cluster pertama terdapat 17 item yang diambil pada 1 tahun terakhir dari tahun 2020 dengan ditandai warna merah tua. Pada cluster kedua terdapat 15 item yang diambil pada 1 tahun terakhir pada dari 2020 dengan ditandai warna merah tua. Pada cluster ketiga terdapat 13 item yang diambil pada 2 tahun terakhir dari tahun 2020 dengan ditandadi warna merah muda. Pada cluster keempat terdapat 12 item yang diambil pada tahun 2 tahun terakhir dari 2020 dengan ditandai warna merah tua, Pada cluster kelima terdapat 7 item yang diambil pada 2 tahun terakhir dari 2020 dengan ditandai merah. Pada cluster keenam terdapat 6 item yang diambil pada 2 tahun terakhir dari 2020 dengan ditandai merah. Pada cluster ketujuh terdapat 5 item yang diambil pada 2 tahun terakhir dari 2020 dengan ditandai merah. Pada cluster kedelapan terdapat 1 item yang diambil pada 2 tahun terakhir dari 2020 dengan ditandai merah.

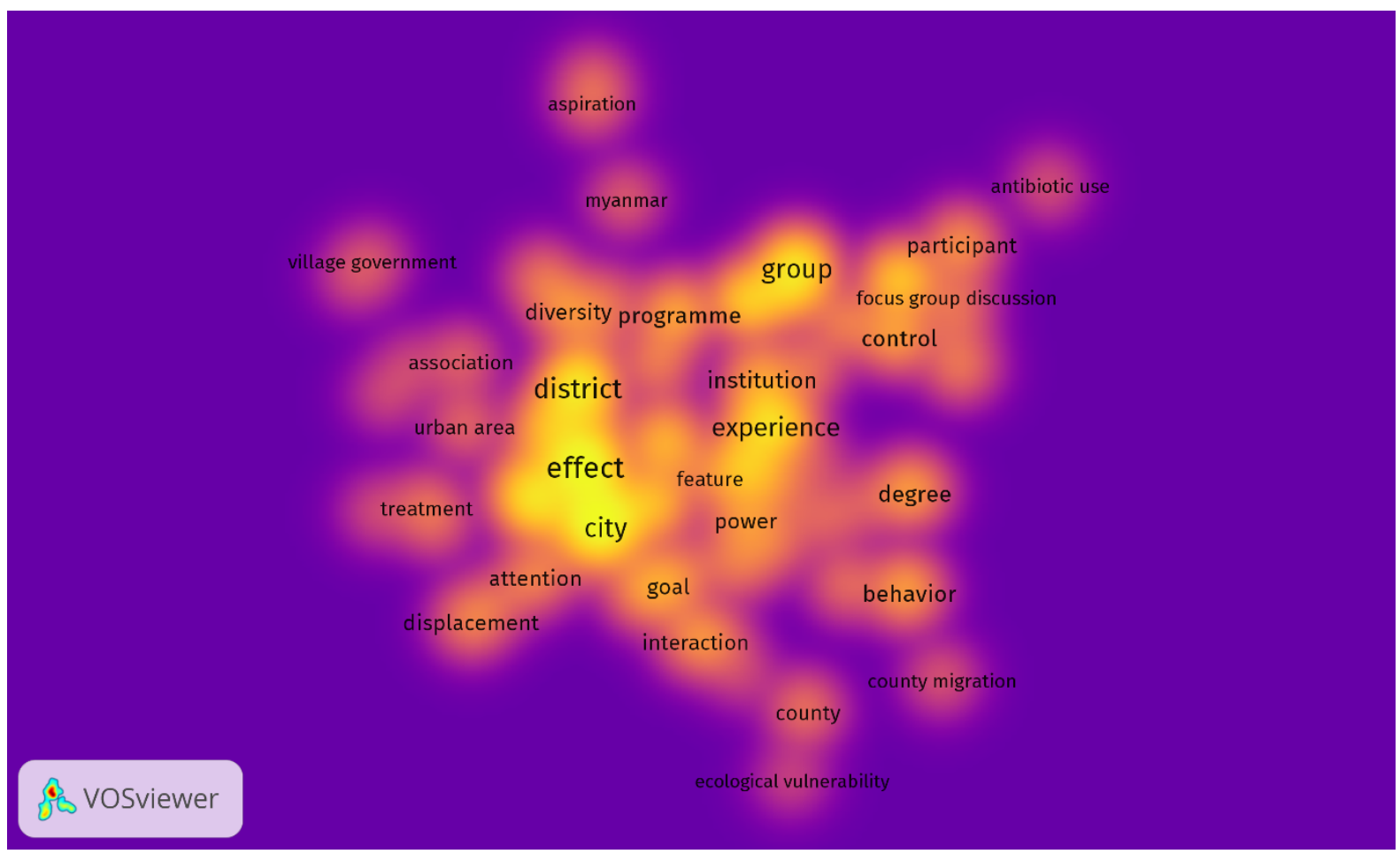

Gambar 4. Konsep Dominan Dilihat dari Density Visualization

\section{3) Density Visualization}

Berdasarkan gambar diatas dapat diketahui topik apa yang menjadi pusat perhatian. Semakin terang warna yang ada maka itu adalah tema yang paling didiskusikan. Jika terdapat warna yang paling pudar artinya tema yang paling tidak banyak didiskusikan, jika warna semakin biru menunjukan bahwa pembahasan topik 
tersebut sedikit, dalam gambar tersebut dapat dilihat jika tema yang paling banyak didiskusikan adalah mengenai effect, district, institution, group.

\section{b. Author Dominan Dalam Studi Collaborative Governance Green Open Space}

Author dan penulis memiliki makna yang berbeda, dimana author memiliki karya yang sifatnnya untuk mengeluarkan ide-ide yang ada dan karyanya lebih bersifat spesifik dan lebih tertutup dari opini publik, sedangkan penulis pada dasarnya adalah seorang yang memperkerjakan dirinya sebagai penulis yang berkarya di lebih dari satu bidang spesifik. Gambar 3. Menunjukkan kumpulan dari beberapa author yang menulis mengenai artikel dengan tema Urban Development Planning. Dalam aplikasi VosViewer, author yang dominan akan muncul dengan ditandai adanya ketebalan warna yang menunjukkan bahwa nama dengan warna yang tebal merupakan author dominan yang mempunyai artikel berkaiatan dengan tema perencanaan pembangunan pedesaan bidang pariwisata ini.

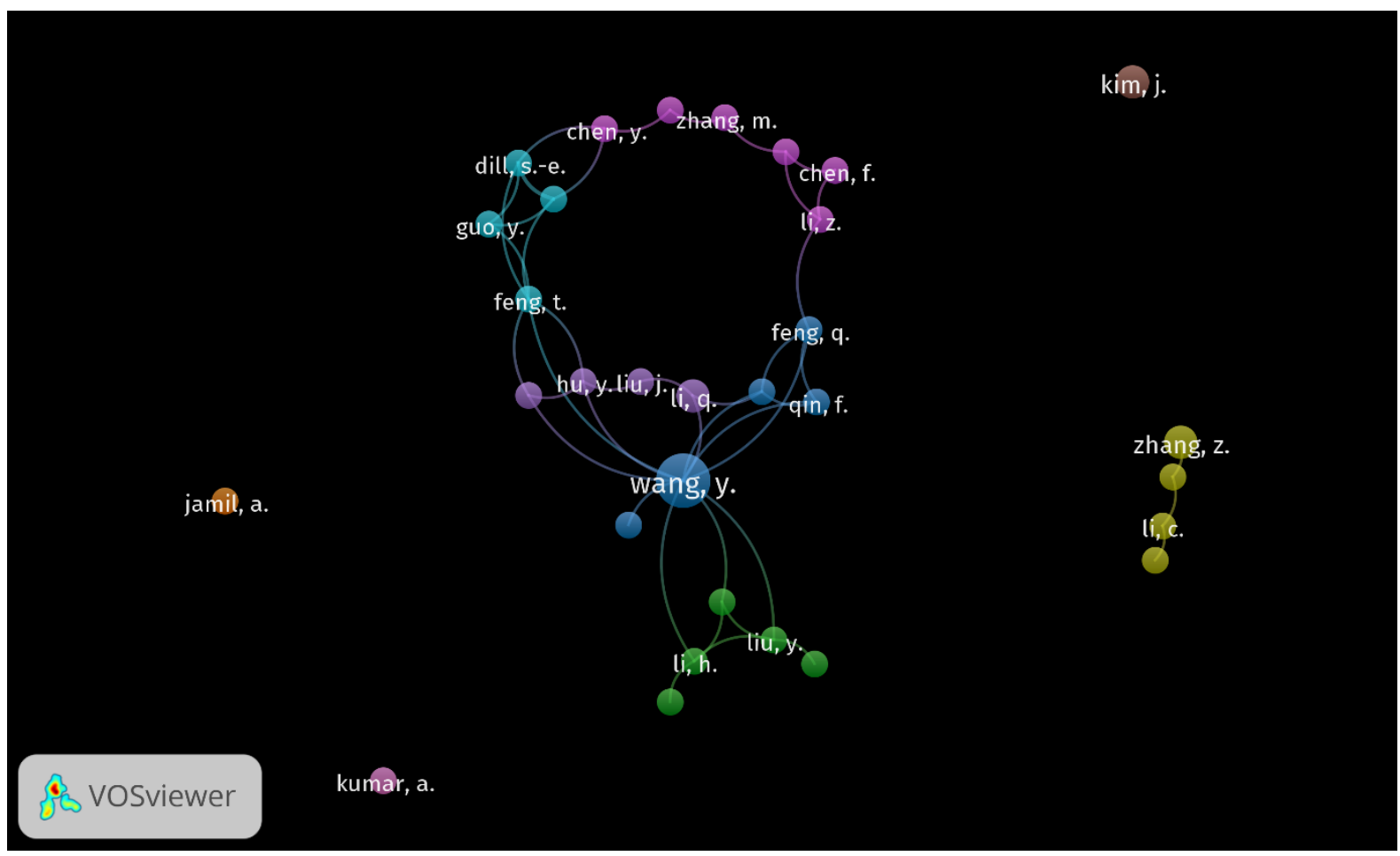

Berfungsi untuk memperlihatkan jejaring antar author yang divisualkan berdasarkan tema Development Planning in Developing Human Resources dengan mencari data melalui scopus dan menggunakan aplikasi vosviewer telah mendapatkan hasil yaitu 7 cluster 51 item tersebut digambarkan dengan beberapa warna seperti pada gambar diatas. Bentuk lingkaran dan tulisan yang berukuran lebih besar menggambarkan bahwa mereka adalah author yang paling dominan dalam clusther masing masing, sedangkan bentuk lingkaran dan tulisan lebih kecil mereka adalah author pendamping atau tambahan yang digambarkan dengan cabang cabang atau garis sesuai dengan warna cluster masing masing. berikut penjelasan author beserta jurnal yang mereka tulis. 
Pada cluster 1 author yang paling dominan adalah "Gao,Y” yang ditandai dengan warna ungu judul jurnal yang ditulis yaitu "Top-Down and Bottom-Up Processes for Rural Development and the Role of Architects in Yunnan, China". Abstrac : Studi ini mengidentifikasi dua proses alternatif tetapi berpotensi simultan untuk pembangunan pedesaan di Cina. Salah satunya adalah pendekatan 'bottom-up' di mana individu dan kelompok penduduk desa bekerja secara inovatif dalam mengembangkan peluang konstruksi bangunan baru, yang didorong oleh metode desain dan konstruksi kontemporer dan asli. Alternatif pendekatan 'top-down' dikaitkan dengan perubahan yang disebabkan oleh pengaruh eksternal, seperti arahan yang diberikan dari sumber pendanaan, dan dorongan untuk penggunaan pengetahuan dan teknologi tertentu; ini kemudian disaring melalui sistem administrasi desa. Dua desa etnis dipelajari di provinsi Yunnan, sebuah wilayah dengan populasi pedesaan berpenghasilan rendah yang lebih besar daripada wilayah lain. Setiap desa memamerkan budaya tradisional yang kuat dan masing-masing telah mengalami pembangunan kembali wisata yang berbeda selama lebih dari sepuluh tahun. Studi kasus menunjukkan adanya ketidaksesuaian antara kategorisasi akademik hunian di desa berdasarkan representasi budaya tradisional yang diciptakan oleh bahan dan teknik, dan persepsi warga desa itu sendiri tentang makna sosial dan budaya dari rumah dan ruang mereka di desa. Hasilnya menunjukkan bahwa arsitek dan desainer dapat memiliki keterlibatan yang berbeda dalam pembangunan pedesaan melalui pembangunan platform untuk diskusi dan pengambilan keputusan, digunakan dengan dan di antara pemangku kepentingan, dan yang dapat menghubungkan dua arah pendekatan yang berbeda.(Gao, 2016)

Pada cluster 2 author yang paling dominan adalah "Huang,Y" yang ditandai dengan warna ungu judul jurnal yang ditulis yaitu "Farewell to Villages: Forced Urbanization in Rural China". Abstrac : Dengan urbanisasi yang cepat di Cina, pola permukiman berubah secara dramatis. Meskipun ada banyak penelitian tentang perubahan di kota-kota Cina, kita tahu relatif sedikit tentang pedesaan meskipun transformasi besar sedang terjadi di pedesaan Cina. Pada pergantian abad ke-21, pemukiman tradisional Tionghoa pedesaan, desa alami dihancurkan secara sistematis, dan penduduk desa dipindahkan ke apartemen dan komunitas perkotaan dengan skala dan kecepatan yang mencengangkan. Urbanisasi paksa yang belum pernah terjadi sebelumnya dengan transformasi sosial ekonomi dan spasial yang mendalam sedang terjadi di sebagian besar pedesaan Cina. Bab ini bertujuan untuk memahami dinamika dan dampak dari urbanisasi yang pesat di pedesaan Cina dengan mengambil pedesaan Provinsi Jiangsu sebagai studi kasus. Penulis berpendapat bahwa keinginan pemerintah daerah akan lebih banyak lahan konstruksi untuk pembangunan ekonomi di bawah sistem manajemen penggunaan lahan yang ketat dan sistem pendapatan berbasis lahan adalah akar penyebab urbanisasi paksa di pedesaan Cina, yang selanjutnya didorong oleh seruan pemerintah pusat untuk mengembangkan pedesaan baru sosialis. Meskipun penduduk desa dapat memperoleh manfaat dari kondisi perumahan yang lebih baik, mereka menderita konsekuensi sosial dan ekonomi yang serius. Urbanisasi yang dipaksakan ini sangat merugikan orang tua dan orang 
miskin, yang membayangi kampanye untuk pedesaan modern dan masyarakat yang harmonis.(Tang, 2017)

Pada cluster 3 author yang paling dominan adalah "Wang, Y" yang ditandai dengan warna ungu judul jurnal yang ditulis yaitu "Urbanization and Informal Development in China: Urban Villages in Shenzhen". Abstrac : Pembangunan perumahan dan industri informal di apa yang disebut desa-desa perkotaan telah menjadi ciri utama dari urbanisasi Tiongkok baru-baru ini. Pada artikel ini kita akan membahas perkembangan desa perkotaan di salah satu kota paling dinamis di Cina - Shenzhen. Artikel pertama mengulas proses urbanisasi dan migrasi di wilayah dan munculnya desa-desa perkotaan. Kemudian memeriksa perkembangan perumahan informal, komersial dan industri di desa-desa ini. Kami menganalisis politik urbanisasi desa dan menyoroti hubungan penting antara migrasi dan pembangunan desa informal. Kami menekankan kontribusi yang dibuat oleh desa-desa perkotaan dalam menyediakan perumahan dan pekerjaan yang terjangkau bagi penduduk berpenghasilan rendah selama urbanisasi yang cepat dan mendesak pertimbangan yang hati-hati terkait dengan pembangunan kembali desa-desa tersebut secara tergesa-gesa dan berskala besar. Kami menyimpulkan bahwa pembangunan kelurahan merupakan bagian yang sangat penting dari proses urbanisasi.

Pada cluster 4 author yang paling dominan adalah "Liu, J" yang ditandai dengan warna ungu judul jurnal yang ditulis yaitu "Low Impact Development Intensive Rural Construction Planning in $\mathrm{Xu}$ Fu Village Ningbo, China: Planning Review through Rural Resilience Perspective". Abstrac: Desa Xu Fu, Ningbo LID, Perencanaan Konstruksi Pedesaan Intensif adalah proyek kerjasama antara Universitas Zhejiang dan Institut Teknologi Ningbo yang dinamai "Program dukungan Sains dan Teknologi Nasional Lima Tahun ke-12 - demonstrasi komprehensif dari teknologi kunci pembangunan pedesaan yang indah dalam daerah urbanisasi di Delta Sungai Yangtze ". Rencana ini berfokus pada pembangunan pedesaan yang intensif sebagai bagian dari pembangunan pedesaan dan proyek konstruksi yang menerapkan prinsip pembangunan berdampak rendah. Desa Xu Fu terletak di Wilayah Delta Sungai Yangtze. Saat ini, pertumbuhan pedesaan membawa dampak pembangunan yang tinggi, sebagai akibat dari pertumbuhan urbanisasi yang pesat sehingga menimbulkan beberapa masalah, seperti efisiensi penggunaan lahan yang rendah, pemukiman pedesaan yang terpencar-pencar, permukiman penduduk yang lebih banyak, jalan-jalan pedesaan yang menutupi, dll. Sementara itu, desa Xu Fu ingin mengembangkan potensi pariwisatanya.

Oleh karena itu, pembangunan pedesaan yang intensif harus dilakukan untuk menghindari efek yang parah. Hasil proyek diharapkan dapat meningkatkan kualitas dan taraf perencanaan, desain, dan konstruksi permukiman pedesaan; memperbaiki lingkungan hidup mereka; menghemat lahan konstruksi dan penggunaan air; dan meningkatkan efisiensi energi. Tujuan dari penelitian ini adalah untuk mengkaji Konstruksi Pedesaan Intensif Pembangunan Berdampak Rendah (LID) di Desa Xu Fu, Kota Ningbo melalui perspektif ketahanan pedesaan. Makalah ini akan mendeskripsikan rencana proyek terlebih dahulu, kemudian mengulasnya melalui perspektif ketahanan 
pedesaan. Makalah ini akan menguraikan teori ketahanan pedesaan dan kemudian meninjau ketahanan pedesaan melalui dua bagian; Bagian pertama adalah mengidentifikasi ketahanan desa dalam pembangunan infrastruktur pedesaan berdasarkan kriteria yang dibuat oleh Ayyob S. dan Yoshiki Y. (2014), tentang kriteria ketahanan kota, dan bagian kedua adalah meninjau ketahanan Desa Xu Fu melalui Arup Resilience Qualities (2012). Mempertimbangkan tiga domain ketahanan pedesaan (ekonomi, ekologi, dan budaya).(Hermaputi \& Hua, 2017) "Xue, L" yang ditandai dengan warna ungu judul jurnal yang ditulis yaitu "Tourism development and changing rural identity in China". Abstrac : Studi ini mengkaji pola dan faktor pendorong terjadinya perubahan identitas di kalangan warga Lembah Chongdu, Cina, yang telah mengalami perkembangan pariwisata sejak pertengahan 1990-an. Menggunakan wawancara semiterstruktur dan observasi partisipan, penelitian ini mengungkap empat jenis perubahan identitas dalam komunitas: (1) transisi dari pengertian kesulitan pedesaan untuk gagasan tentang fasilitas pedesaan; (2) transisi yang sesuai dari pengertian rasa malu pedesaan menjadi rasa kebanggaan pedesaan; (3) peningkatan identitas komunitas secara keseluruhan; dan (4) identitas pedesaan menjadi kurang 'pedesaan. " Perubahan identitas penduduk dapat dikaitkan dengan tiga faktor: kebijakan pemerintah yang bergeser, standar hidup yang lebih baik, dan interaksi tuan rumah-tamu. Temuan menunjukkan bahwa perubahan materi yang dibawa oleh pembangunan pariwisata bisa berdampak pada perubahan identitas pedesaan warga.(Xue et al., 2017)

Pada cluster 5 author yang paling dominan adalah "Qiao, W" yang ditandai dengan warna ungu judul jurnal yang ditulis yaitu "Land-Use Transition of Tourist Villages in the Metropolitan Suburbs and Its Driving Forces: A Case Study of She Village in Nanjing City, China". Abstrac: Dalam konteks transisi dari "Cina Pedesaan-Asli" ke "Cina PedesaanPerkotaan", desa-desa pinggiran kota telah mengalami rekonstruksi format, industri, dan fungsi yang cepat. Bertujuan untuk mengungkap karakteristik evolusi dan kekuatan pendorong, studi ini memilih She Village, yang terletak di daerah pinggiran kota Nanjing, untuk menganalisis perubahan morfologi dominan dan resesif penggunaan lahan dengan menggunakan penilaian pedesaan partisipatif, penginderaan jauh, dan sistem informasi geografis. Hasil penelitian menunjukkan bahwa She Village mengalami tiga tahap, termasuk pengembangan industri, restorasi ekologi, dan pengembangan industri jasa, dari 1980 hingga 2018, dengan mode pengelolaan yang lebih beragam, penggunaan lahan multifungsi, dan fragmentasi lahan yang semakin intensif. Penggeraknya termasuk sumber daya alam, pertumbuhan populasi, kebijakan Grain for Green, permintaan pasar perkotaan, dll., Yang intensitasnya menunjukkan tren "naik-naik-naik", "naik-turunturun", "sesekali", dan "naik-turunkan-naikkan" secara bergantian. Desa wisata menjalani tiga tahap pembangunan industri, pembangunan pertanian, dan pengembangan industri jasa, dengan karakteristik berkala didorong oleh kebijakan topdown, kekuatan desa endogen, dan radiasi dan difusi kota. Penelitian ini memperdalam pemahaman tentang proses pembangunan desa suburban dan menjadi acuan dalam 
pembuatan dan perencanaan kebijakan pertanahan di desa lain yang sejenis.(Chai et al., 2021)

Pada cluster 6 author yang paling dominan adalah "Feng, T" yang ditandai dengan warna ungu judul jurnal yang ditulis yaitu "Land-Use Transition of Tourist Villages in the Metropolitan Suburbs and Its Driving Forces: A Case Study of She Village in Nanjing City, China". Abstrac: Dalam konteks transisi dari "Cina Pedesaan-Asli" ke "Cina PedesaanPerkotaan", desa-desa pinggiran kota telah mengalami rekonstruksi format, industri, dan fungsi yang cepat. Bertujuan untuk mengungkap karakteristik evolusi dan kekuatan pendorong, studi ini memilih She Village, yang terletak di daerah pinggiran kota Nanjing, untuk menganalisis perubahan morfologi dominan dan resesif penggunaan lahan dengan menggunakan penilaian pedesaan partisipatif, penginderaan jauh, dan sistem informasi geografis. Hasil penelitian menunjukkan bahwa She Village mengalami tiga tahap, termasuk pengembangan industri, restorasi ekologi, dan pengembangan industri jasa, dari 1980 hingga 2018, dengan mode pengelolaan yang lebih beragam, penggunaan lahan multifungsi, dan fragmentasi lahan yang semakin intensif. Penggeraknya termasuk sumber daya alam, pertumbuhan populasi, kebijakan Grain for Green, permintaan pasar perkotaan, dll., Yang intensitasnya menunjukkan tren "naik-naik-naik", "naik-turunturun", "sesekali", dan "naik-turunkan-naikkan" secara bergantian. Desa wisata menjalani tiga tahap pembangunan industri, pembangunan pertanian, dan pengembangan industri jasa, dengan karakteristik berkala didorong oleh kebijakan topdown, kekuatan desa endogen, dan radiasi dan difusi kota. Penelitian ini memperdalam pemahaman proses pembangunan desa suburban dan menjadi acuan dalam pembuatan dan perencanaan kebijakan pertanahan di desa lain yang sejenis.(Chai et al., 2021) "Research on the Development Strategies of Rural Tourism in Suzhou Based on SWOT Analysis". Abstrac: Pariwisata pedesaan dapat memanfaatkan sepenuhnya sumber daya pariwisata di daerah pedesaan untuk menyesuaikan dan mengoptimalkan struktur industri pedesaan, memperluas rantai industri pertanian, mengembangkan layanan pariwisata pedesaan, mempromosikan lapangan kerja nonpertanian, meningkatkan pendapatan petani, dan menciptakan basis ekonomi yang lebih baik untuk pembangunan pedesaan baru. Makalah ini menggunakan metode tersebut analisis SWOT untuk membuat evaluasi dan analisis yang komprehensif tentang kekuatan, kelemahan, peluang dan ancaman dalam pengembangan pariwisata pedesaan di Suzhou. Melalui kombinasi sumber daya internal dan eksternal lingkungan, makalah ini dengan jelas menentukan keuntungan dan kerugian dari sumber daya pedesaan Suzhou, memahami peluang dan tantangan yang akan dihadapi, dan juga mengusulkan tindakan penanggulangan yang sesuai. Akhirnya, tulisan ini berharap dapat memberikan referensi keputusan untuk pengembangan pariwisata pedesaan di Suzhou, dan mempromosikan berkelanjutan pengembangan pariwisata pedesaan di Suzhou (Zhang, 2012).

Pada cluster 7 author yang paling dominan adalah "Jamil, A" yang ditandai dengan warna ungu judul jurnal yang ditulis yaitu "IMPLEMENTASI INDEKS DESA ZAKAT PADA DESA SUNGAI DUA KECAMATAN RAMBUTAN (Untuk Desa yang Terukur dan 
Berkemajuan)". Abstrac: BAZNAS sebagai pusat pengelolaan zakat nasional menyelengggarakan program pemberdayaan zakat dalam bentuk program pengembangan desa binaan yaitu program Zakat Devoplement Community.Program ini adalah pemberian bantuan zakat produktif pada desa-desa yang membutuhkan. Dalam membangun dan memberdayakan desa diperlukan suatu standar pengukuran sebagai acuan bagi stakeholder seperti pemerintah guna perencanaan pengembangan desa dengan tepat.Penelitian ini menggunakan metodemixed method research, yaitu gabunganmetode kualitatif dan kuantitatif. Alat analisis yang digunakan adalah Indeks Desa Zakat (IDZ) dengan penghitungan metode multi-stage weighted index.Penelitian ini bertujuan untuk menganalisis desa Sungai Dua dan mengukurnya apakah diprioritaskan untukdibantu dana zakat atau tidak.Hasil penelitian menunjukkan bahwa desa Sungai Dua dikategorikan Baik dengannilai sebesar 0.65 dan diinterpretasikan tidak diprioritaskan untuk dibantu dana zakat.(Jamil, 2018) "STRATEGY OF TOURISM VILLAGE DEVELOPMENT BASED ON LOCAL WISDOM" Abstrac: Salah satu alternatif pembangunan yang ada saat ini adalah Pengembangan Pariwisata terutama di pedesaan pariwisata. Masalah mendasar adalah bagaimana strategi yang tepat untuk mencapai hal tersebut tujuan pembangunan. Pengembangan desa wisata dapat mempertimbangkan potensi sektor ekonomi lokal, pemerintah, swasta, formal, dan informal serta internal dan kelompok kepentingan eksternal. Studi ini berupaya mengungkap strategi yang tepat dalam mengembangkan pariwisata di desa Telaga Biru Bangkalan berbasis sumber daya lokal. Pelajaran ini menggunakan tinjauan pustaka dengan pendekatan pengembangan pariwisata dengan metode kualitatif bingkai. Data tersebut berupa interpretasi hasil penelitian yang dipublikasikan secara nasional dan jurnal internasional yang dianalisis secara deskriptif untuk menghasilkan kesimpulan. Itu Hasil dari penelitian ini berupa rumusan bentuk pariwisata dalam paket wisata yang meliputi sekolah membatik, permainan tradisional madura, dan pertunjukan kesenian tradisional daerah kuliner khas, dan penginapan dengan konsep Tanean Lanjhang. Strategi untuk Pelaksanaan program Desa Wisata Batik melalui tahapan, diantaranya Pertama, meningkatkan kapasitas masyarakat dengan pengetahuan sebagai target utama Pengetahuan, Sikap dan Praktik (KAP) masyarakat setempat melalui berbasis masyarakat kegiatan pendidikan dan pelatihan (CBT). Kedua, inventarisasi sumber daya manusia untuk lokal pemandu, instruktur sekolah batik, tim permainan tradisional madura, kuliner madura penyedia. Ketiga, pelembagaan pengelolaan desa wisata di tingkat desa akan bertanggung jawab atas kelestarian desa wisata. Keempat, upaya menjembatani dan menghubungkan dengan dinas pariwisata Bangkalan dan investor. Kelima, kerja sama dengan biro perjalanan di Madura. Keenam, branding, dan promosi melalui media sosial dan situs desa wisata. Menerapkan strategi ini akan menciptakan turis baru Tujuannya, "Kampung Wisata Batik" dalam bentuk yang berbeda dan akan menambah masyarakat ekonomi dan pendapatan daerah.(Lubis et al., 2020)

Pada cluster 8 author yang paling dominan adalah "Kim, J" yang ditandai dengan warna ungu judul jurnal yang ditulis yaitu "Ecotourism Market Segmentation in Bali, 
Indonesia: Opportunities for Implementing REDD+". Abstrac: Ekowisata telah dipromosikan di banyak wilayah di Indonesia sebagai platform yang layak untuk mengurangi emisi dari deforestasi dan degradasi hutan di negara berkembang (REDD +) dengan memberikan insentif kepada masyarakat lokal untuk upaya konservasi hutan mereka. Kajian ini bertujuan untuk menemukan peluang penerapan REDD + di Bali melalui analisis segmentasi pasar ekowisata, dan untuk memberikan implikasi kebijakan bagi negara berkembang lain dalam keadaan serupa. Hasilnya menunjukkan bahwa dua cluster - "turis bertanggung jawab yang mencari alam" dan "turis bertanggung jawab yang mencari kesehatan" - dipilih sebagai cluster target Bali. Karena keduanya memiliki motivasi yang lebih tinggi dan sikap yang lebih bertanggung jawab dibandingkan cluster lainnya, mereka tidak hanya mampu menjaga hubungan simbiosis antara destinasi ekowisata dan pengunjung, tetapi juga menarik wisatawan potensial dengan karakteristik serupa, yang pada akhirnya berkontribusi pada bisnis pariwisata berkelanjutan di Indonesia. wilayah. Kesimpulannya, membangun strategi pemasaran berdasarkan pemahaman para wisatawan akan mendorong pelestarian hutan secara efektif, sekaligus memainkan peran penting dalam implementasi REDD + dengan membawa pendapatan pariwisata berkelanjutan bagi masyarakat lokal.(Choi et al., 2020)

Pada cluster 9 author yang paling dominan adalah "Kumar, A" yang ditandai dengan warna ungu judul jurnal yang ditulis yaitu "Tourism as a Poverty Eradication Tool for Rural Areas in Selangor, Malaysia". Abstrac: Makalah ini menyajikan pemahaman tentang kontribusi yang dibuat oleh pariwisata terhadap pengentasan kemiskinan di daerah pedesaan tertentu di Selangor, Malaysia. Program homestay pedesaan sebagai produk pariwisata yang layak di Malaysia memiliki skala yang relatif kecil dan masih merupakan pasar yang pertumbuhannya lambat meskipun berbagai insentif ditawarkan kepada operator oleh pemerintah untuk mengembangkan pasar ini. Kemiskinan merupakan akar penyebab berbagai penyakit sosial seperti buta huruf, kriminalitas, penyalahgunaan narkoba dan tingginya angka perceraian. Meskipun pariwisata telah diadopsi sebagai strategi pengentasan kemiskinan di Selangor, hal itu belum sepenuhnya dimanfaatkan oleh masyarakat pedesaan dan mereka yang telah mengalami kesulitan untuk mempertahankannya. Penelitian ini dilakukan dengan tujuan menyusun model (atau mengidentifikasi variabel) yang akan menjamin keberlanjutan ekonomi program homestay pedesaan di Selangor, Malaysia. Melalui analisis faktor, variabel keterlibatan masyarakat dalam kegiatan pariwisata diidentifikasi.(Kumar et al., 2012) 


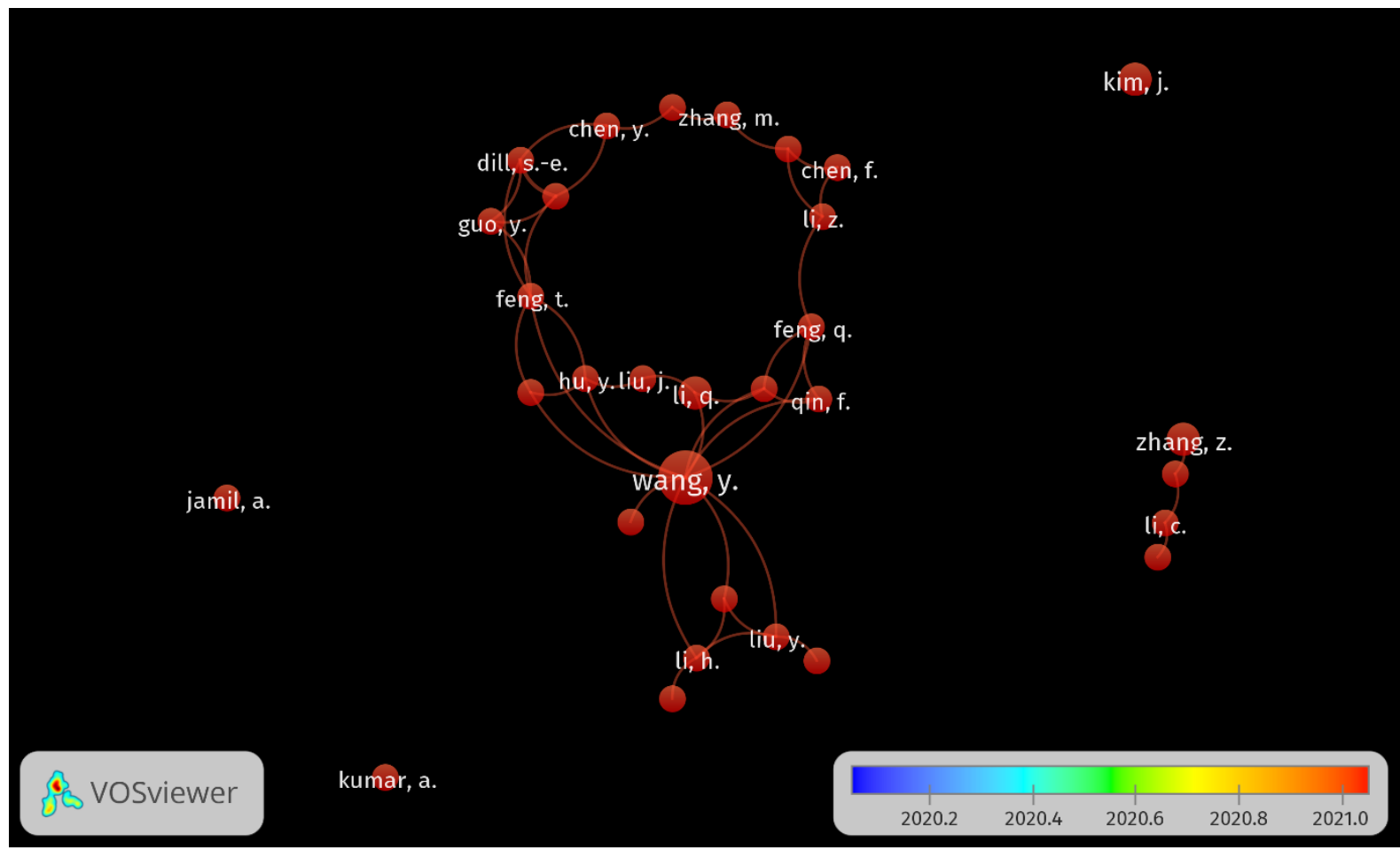

Berdasarkan gambar diatas, warna yang paling terang menunjukan penulis dengan hasil publikasi terbanyak. Penulis dengan hasil publikasi terbanyak yaitu, Wang, Y, Zhang, Y,Chen, F. Hasil publikasi dari penulis Wang, Y yaitu berjudul Urbanization and Informal Development in China: Urban Villages in Shenzhen. Begitupun sebalikanya penulis dengan warna paling pudar maka penulis tersebut masih sedikit mempubliskasikan karyanya.

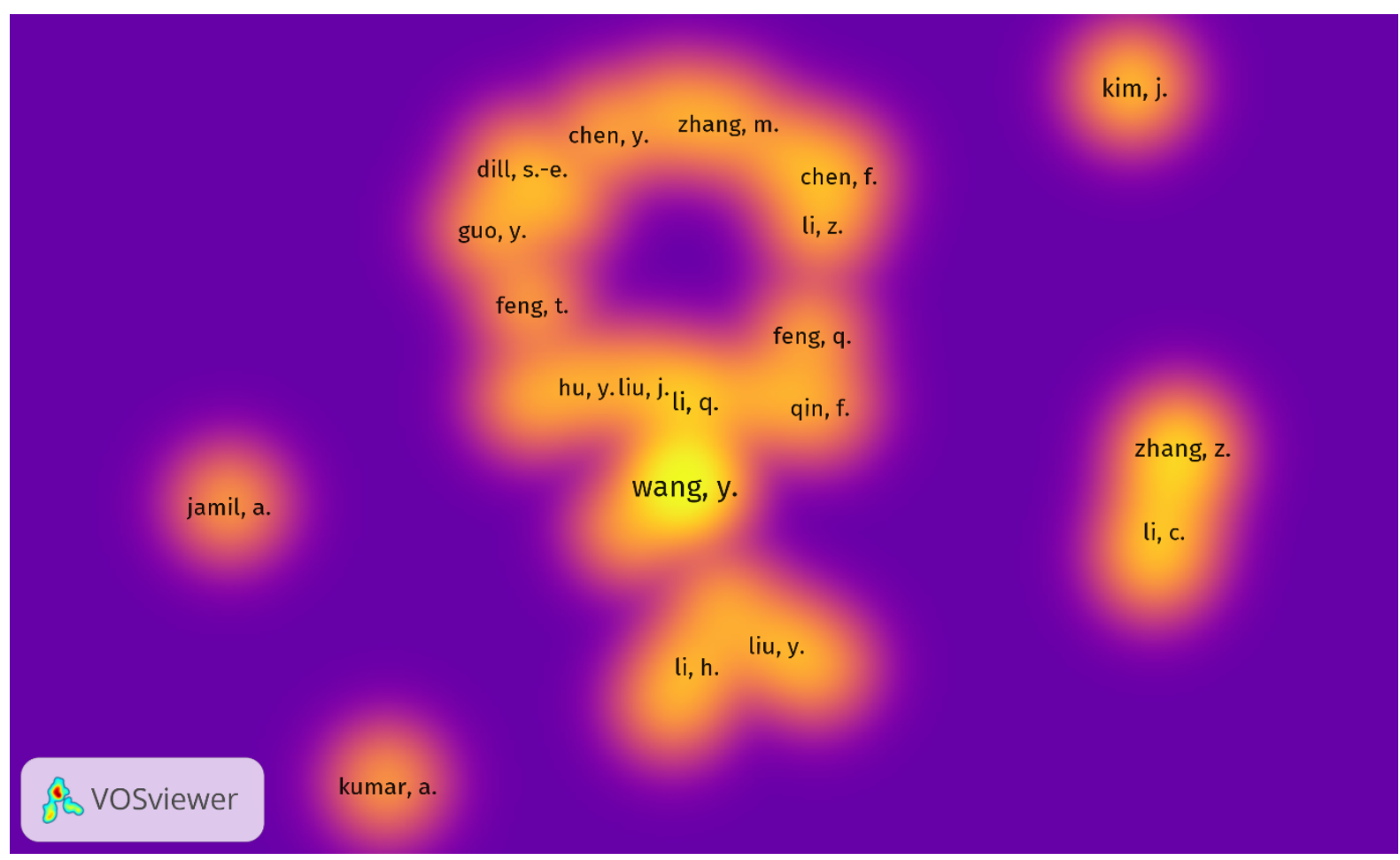




\section{Kesimpulan}

Pada cluster 1 author yang paling dominan yaitu "Gao, Y" telah menerbitkan jurnal yang berjudul Top-Down and Bottom-Up Processes for Rural Development and the Role of Architects in Yunnan, China telah terbit pada akhir dari tahun 2020 yang ditandai dengan warna Merah.

Pada cluster 2 author yang paling dominan yaitu "Huang, Y" telah menerbitkan jurnal yang berjudul Farewell to Villages: Forced Urbanization in Rural China telah terbit pada akhir dari tahun 2020 yang ditandai dengan warna Merah.

Pada cluster 3 author yang paling dominan yaitu "Wang, Y" telah menerbitkan jurnal yang berjudul Urbanization and Informal Development in China: Urban Villages in Shenzhen telah terbit pada akhir dari tahun 2020 yang ditandai dengan warna Merah.

Pada cluster 4 author yang paling dominan yaitu "Liu, J" telah menerbitkan jurnal yang berjudul Low Impact Development Intensive Rural Construction Planning in Xu Fu Village Ningbo, China: Planning Review through Rural Resilience Perspective telah terbit pada akhir dari tahun 2020 yang ditandai dengan warna Merah.

Pada cluster 5 author yang paling dominan yaitu "Qiao, W" telah menerbitkan jurnal yang berjudul Land-Use Transition of Tourist Villages in the Metropolitan Suburbs and Its Driving Forces: A Case Study of She Village in Nanjing City, China telah terbit pada akhir dari tahun 2020 yang ditandai dengan warna Merah.

Pada cluster 6 author yang paling dominan yaitu "Feng, T" telah menerbitkan jurnal yang Land-Use Transition of Tourist Villages in the Metropolitan Suburbs and Its Driving Forces: A Case Study of She Village in Nanjing City, China telah terbit pada akhir dari tahun 2020 yang ditandai dengan warna Merah.

Pada cluster 7 author yang paling dominan yaitu "Jamil, A" telah menerbitkan jurnal yang berjudul IMPLEMENTASI INDEKS DESA ZAKAT PADA DESA SUNGAI DUA KECAMATAN RAMBUTAN (Untuk Desa yang Terukur dan Berkemajuan) telah terbit pada akhir dari tahun 2020 yang ditandai dengan warna Merah.

Pada cluster 8 author yang paling dominan yaitu "Kim, J" telah menerbitkan jurnal yang berjudul Ecotourism Market Segmentation in Bali, Indonesia: Opportunities for Implementing REDD+ telah terbit pada akhir dari tahun 2020 yang ditandai dengan warna Merah.

Pada cluster 9 author yang paling dominan yaitu "Kumar, A" telah menerbitkan jurnal yang berjudul Tourism as a Poverty Eradication Tool for Rural Areas in Selangor, Malaysia telah terbit pada akhir dari tahun 2020 yang ditandai dengan warna Merah. 


\section{Daftar Pustaka}

Chai, Y., Qiao, W., Hu, Y., He, T., Jia, K., Feng, T., \& Wang, Y. (2021). Land-use transition of tourist villages in the metropolitan suburbs and its driving forces: A case study of she village in Nanjing city, China. Land, 10(2), 1-18. https://doi.org/10.3390/land10020168

Choi, G., Kim, J., Sawitri, M. Y., \& Lee, S. K. (2020). Ecotourism market segmentation in Bali, Indonesia: Opportunities for implementing REDD+. Land, 9(6), 1-15. https://doi.org/10.3390/LAND9060186

Gao, Y. (2016). Top-down and bottom-up processes for rural development and the role of architects in Yunnan, China. Buildings, 6(4). https://doi.org/10.3390/buildings6040047

Hermaputi, R. L., \& Hua, C. (2017). Low Impact Development Intensive Rural Construction Planning in Xu Fu Village Ningbo, China: Planning Review through Rural Resilience Perspective. Jurnal Wilayah Dan Lingkungan, 5(2), 95. https://doi.org/10.14710/jwl.5.2.95-112

Jamil, A. (2018). IMPLEMENTASI INDEKS DESA ZAKAT PADA DESA SUNGAI DUA KECAMATAN RAMBUTAN (Untuk Desa yang Terukur dan Berkemajuan). KHOZANA : Jurnal Ekonomi Dan Perbankan Islam, 1(2), 245-257.

Kumar, R., Gill, S. S., \& Kunasekaran, P. (2012). Tourism as a Poverty Eradication Tool for Rural Areas in Selangor, Malaysia. Global Journal of Human Social Science, 12(7), 2126.

Lubis, H., Rohmatillah, N., \& Rahmatina, D. (2020). Strategy of Tourism Village Development Based on Local Wisdom. Jurnal Ilmu Sosial Dan Humaniora, 9(2), 320. https://doi.org/10.23887/jish-undiksha.v9i2.22385

Tang, Z. (2017). China's urbanization and socioeconomic impact. China's Urbanization and Socioeconomic Impact, April, 1-227. https://doi.org/10.1007/978-981-10-4831-9

Xue, L., Kerstetter, D., \& Hunt, C. (2017). Tourism development and changing rural identity in China. Annals of Tourism Research, 66, 170-182. https://doi.org/10.1016/j.annals.2017.07.016

Yoeti. (2017). Strategi Pemerintah Daerah Dalam Mengembangkan Objek Wisata Di Kabupaten Bolaang Mongondow Utara. Jurnal Eksekutif, 2(2).

Zhang, X. M. (2012). Research on the development strategies of rural tourism in Suzhou based on SWOT analysis. Energy Procedia, 16(PART B), 1295-1299. https://doi.org/10.1016/j.egypro.2012.01.207 